\title{
The Implementation of Strategic Management of Education in Increasing Sustainable Competitive Advantage through Strategic Alliances: a case study at Bandung and Bali Institute of Tourism Ministry of Tourism, Indonesia
}

\author{
Herlan Suherlan \\ Lecturer, Department of Tourism Bandung Institute of Tourism \\ Bandung - 40141, Indonesia \\ E-mail: hel@stp-bandung.ac.id
}

\begin{abstract}
Competitiveness, excellences and quality are strategic issues and a big agenda and of Bandung and Bali Institute of Tourism (STP) and the Deputy of Tourism Institutional Development of the Ministry of Tourism. To realize their vision and mission, the two institutions are faced with a number of challenges especially regarding the resources (educators, physical facilities, finance). Therefore, in this tight and fast-changing era of globalization, efforts to conduct and develop strategic alliances with all stakeholders is a must. This study aims to determine and assess empirical overview of strategic issues faced and strategies undertaken in response to the needs of human resource development as well as future strategic alliances that were done by STPs to respond to global competition. This study uses a qualitative method with case study approach, and the data is collecting technique used is interview, observation and document study. The sampling technique used is purposive. The analysis of data is performed through the display data, data reduction and verification of data through triangulation process. The results shows that in facing the global competition STPs are faced with a number of internal and external strategic challenges, and to achieve their goals it can not be done alone but they should form an alliance with all stakeholders. STP performs various strategic measures through the internal and external improvement. Strategic alliances with other institutions is done by focusing on the improvement of the quality of education towards the world class tourism, giving the priority on the provision of education (joint program), on the job training, recruitment of graduates, the support of the development of tourism educational institutions, and optimization of the implementation of the three responsibilities, both in terms of quantity and quality, as well as the establishment of a research culture for the teachers.
\end{abstract}

Keywords-Strategic Management, Strategic Alliance, Sustainable Competitive Advantage, Tourism Education

\section{INTRODUCTION}

Tourism has a snowball effect in contributing to economic growth, for the development of new tourism destinations are often accompanied by the advent of nongovernmental organizations the new society [14]. Unfortunately, the human factor is only considered to be an other expense and not an input or even assets that can give added value to the tourist experience. Therefore, the expertise of human resources is not a relevant issue and tourism education is just a skills training and limited to specific expertise eye [9]. But now, with the complexity segmentation growing demand, globalization of markets and the flexibility resulting from new technologies and the search for synergy as a source of profits through a pooling diagonally has led to changes in the form of the paradigm of tourism business dramatic, or so-called Fayos, Munez, $\&$ Fuentes [10] as a new age of tourism. In fact, the future of the tourism industry is very dependent on the ability to have a competitive edge, which means it has the ability to achieve and sustain gains above business sectors other is the reference in this business, even in the process of adapting to the changes that continue to occur [8].

The competitiveness of the tourism industry is determined by the quality of the industry based on business standards and quality of human resources is based on tourism and higher education curriculum standards of competence [11]. The development of the education system and the implementation of educational programs specifically in the field of higher education is needed to improve the professionalism of human resources in the tourism industry and the overall competitiveness [12]. This effort is an important thing to do for the implementation of a mechanism for harmonious interaction between the components of education [2]. 
Tourism sector, not only requires technical workforces but also ones with in various levels of competence, namely: scientists; technocrats; professionals; and technical workforces [1]. As matter of fact, graduates of both Bandung and Bali Tourism Institute (STP) and both Medan and Makassar Academy of Tourism (AKPAR) have not been able to occupy positions that fit their education levels. A research conducted by the Central Bureau of Statistics from 2006 to 2010, about tourism sector labor force condition showed that there are 3\% workers with university educational backgrounds of the total population of 22,212,885 people with 15 years or older workers who work in the previous trade and tourism. So, it is normal that workers in services sector such as tourism, especially the hospitality has been widely categorized as 'low skills' in the academic literature [2]. It shows that the tourism sector is not only a shortage of human resources at intermediate level (executor) at S1 level, but also shortage of human resources with university education background as a strategic development and policy maker. Specifically, the distribution of STP Bandung graduates, based on field work, showing great most of alumni occupy the level of the staff $(77 \%)$ and only $2 \%$ who are at supervisor level. This fact does not match with the learning objectives of Diploma III programme that supposed to occupy at least supervisor level.

In a broader scale at regional and international level, Indonesia's tourism human resources are still competitive for position of craft level with those from Philippines, India, China and Thailand. While Singapore and Malaysia have begun to unveil human resources at middle management level. At the top management level, human resources from the USA Australia and Europe still occupy the first rank. The condition is exacerbated by the fact that most of the practitioners, policy makers, and tourism business players are not armed with tourism education background. But rather from various disciplines who then seek to improve their knowledge by learning by doing [4]. Moreover, at this time, those who have authority as tourism policy makers, many of them came from non tourism magister or doctoral education background. Though they should have the ability as a visionary in the field of tourism, which do not just think of contemporary and ego, but also to think ahead and to act-as-us [5].

The background and the identification of phenomena above provide information that strategic management is indispensable as a solution to human resource development in tourism education in facing the increasingly complex global competition. To implement the strategic management, educational institutions can not act their own, but it must be done through networking and partnerships with other educational institutions and even with all stakeholders.

\section{METHOD}

a. Research Design

This study used a qualitative research design with a case study approach that seeks to understand and interpret the meaning of events interaction of human behavior in a given situation. Ghony [3] suggested that the case study is a research that is directed to collect data, extract meaning, and gain an understanding of the case.

Schematically, the research design developed in the study regarding the implementation of strategic management as an ongoing effort to improve competitive capability through strategic alliances at STPs, presented in Figure 1.

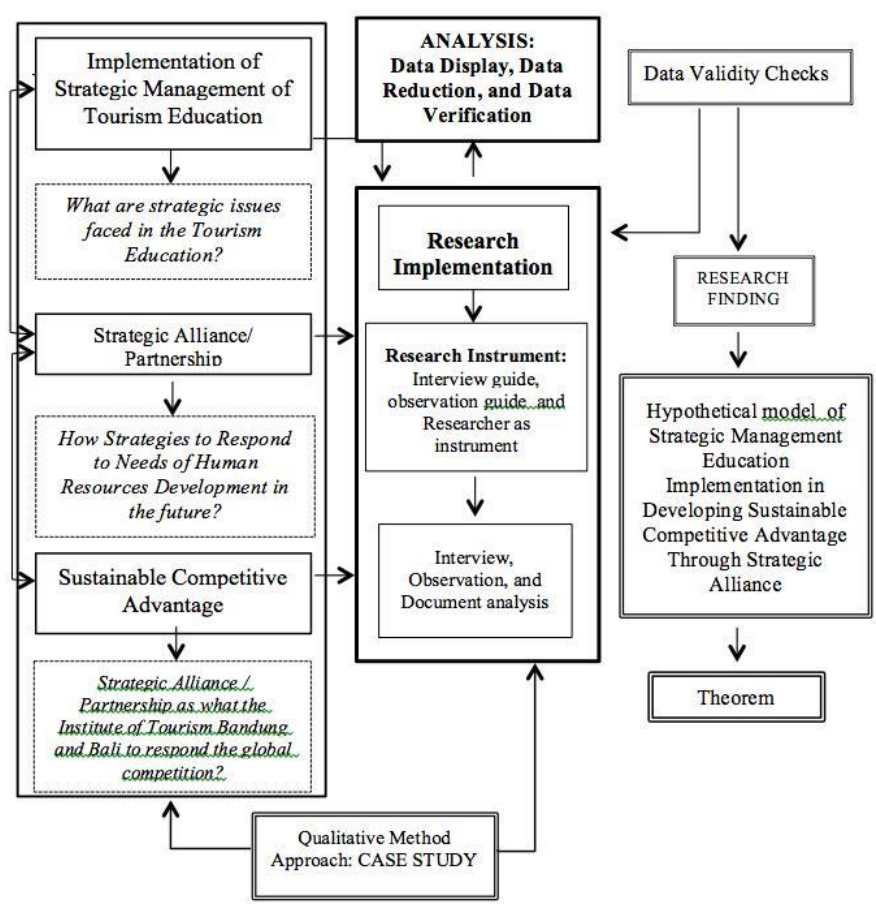

Figure 1: Research Design

In essence, a qualitative research is a research procedure that produces descriptive data in the form of written or spoken words of people and observed behavior $[21,22]$. In this study subject of observation was human as a key instruments, that is, people either as informants or education management policies maker in STPs. By using qualitative methods, as required by the research problems, namely the quality and competitiveness of higher education in a sustainable manner, the development of information obtained became fuller, deeper, more meaningful so that the research objectives will be achie 
b. Data Collection

1) Interview

In qualitative research the most important tool for data collection interview, it enabled researcher to obtain indepth information. Interviews were conducted with key informants who know the key issues related to the research problem. In-depth interviews are interviews conducted by bringing the informants to speak freely and deeply.

Informants of this research were, among other, (1) the Head Deputy of Tourism Institutional Development of the Ministry of Tourism; (2) the Leaders of STPs, i.e the Directors, the Deputy Directors, and the Chief of Departments, (3) lecturers, and (4) the tourism industry, the users graduates and also as a medium for obtaining such data that is hard to obtain from the free interviews or also as a way to cross control of correctness of the obtained data during the study. In-depth interviews with informants were conducted from 2012 to 2013.

\section{2) Observation}

The observations were made to see how the educational activities at STPs, with regard to the learning activities of both theory and practice. Observations were also done to see the extent to which facilities and pre infrastructure and other education supporting facilities can support the process of education at STPs, which covers the classes for theory lectures, the practical facilities, computer labs, library, student dormitories, canteens, and various other supporting facilities.

The results of the above observations are very useful to confirm or as a data triangulation of the results of in-depth interviews.

\section{3) Document Assessment}

Document assessment conducted by examining relevant and necessary documents for the research, among others, (1) Rules and Regulations; (2) Strategic Plans of the Ministry of Tourism and STPs;

(3) Statuta of STPs; (4) Manual of Academic; (5) Documents of Cooperation; and (6) other documents both print and electronic.

\section{c. Data Analysis}

The analysis of the data were conducted qualitatively by means of repeated and continuous between the collection and analysis of data, both for data collection in the field and after the data are collected [7, 21, 22]. The results of the data analysis are presented systematically in respective to each institution to generate conclusions as research findings in the form of description or an analytical explanation.
All stages in the procedure of qualitative research commonly known as analytical steps of data with three path activities that occur simultaneously in the forms of data reduction, data presentation or display, and conclusion or verification. Then, analysis is followed by evaluation in accordance with the set forth criteria. All data collected through interviews, documentary studies, observations, were then analysed. The data analysis is done is through the stages of coding, categorization, reduction, and display data.

\section{d. Validity of Finding Process}

To maintain the validity or trust of the findings of research several ways was carried out. The validity of data need to be tested using triangulation techniques or combination of methodologies. In this study, there are two things that can be done in the process of triangulation, by triangulation of data sources and triangulation of methods.

\section{FINDING AND DISCUSSION}

\section{a. Strategic problems in tourism education in Indonesia}

There are a number of obstacles encountered in generating competent human resources of graduates of STPs. The research results concerning the competence of graduates showed that the strategic problems faced by STPs concerned with not optimal of human resources quality, both lecturers, educators and graduates; facilities and infrastructure of education did not support from both of quantity and quality perspective; and the learning process is not yet fully in accordance with national education standards.

There are a number of constraints regarding the determinants of the quality of graduates of STPs in entering the global market, that the quality of tourism higher education graduates is affected by all factors involved in the system and sub-system of education, ranging from educational inputs, processes for education, and post education.

Constraints related to the fulfillment of quality standard of graduates of STPs in entering the global market, located on optimizing the delivery of education both in connection with curricular (TLA or Teaching Learning Activity) as well as co-curricular in preparing students competencies.

Strategic issues related to the quality of lecturers that have global competitiveness in STPs showed that the lecturers STP until present time have not been able to compete at international level. There are no educators of STP that has gained international recognition both in teaching, research and community service. 
The main problem is the lack of opportunity to participate in various international events, such as congresses, conventions, international conferences, and to produce and publish academic journal articles that have an international scope.

b. The strategic policy to respond to the needs of human resource development in the future

STPs has made strategic steps to improve the quality TLA, as outlined in the Strategic Plan document. Even, the efforts of improving the quality of TLA in STP Bandung are included in the Master Plan Development of the institution. All the elements related to the educational process should refer STPs functions as the vocational higher education that have their own stages of learning process, output and its outcomes are different from the university. The learning process in the field of vocational education applies ratio between theory and practice 50:50, and it is orientated toward student learning center so that its output not only has good skills, but also soft skills, so graduates are better prepared to enter the world of industry. Therefore, in the learning process, students should be introduced to the real conditions on the tourism field, by doing such field practices or inviting practitioners from industry to give guest lectures. To be able to realize those mentioned objectives, of course a large budget is required. Therefore, the budget in DIPA of STPs must be adapted to the stages of vocational education. Internal correction also done through changes in statute as an institution effort to anticipate the needs of future development.

Some strategic policies at STPs regarding the improvement of external carried out by STPs is through cooperation / partnership with universities at home and abroad with the aim of preparing qualified human resources according to market needs corresponding to the vision of the institutions as a centers of excellence in the tourism sector through strategic planning, implementation, and evaluation to improve the quality of faculty and curriculum.

Some strategic policies at STPs involves revamping the curriculum, conducted by adjusting the curriculum based on competency (CBC) with market needs and implementing the curriculum that refers to the white paper which act as the base of curriculum reform, and assessment reform curriculum is done every year by involving practitioners of the tourism industry as well as experts in the field of tourism.
Strategic policy of the fulfillment of lecturers quality into internationally competitive at STPs is by improving lecturers quality through creating a functional educators projection map of up to the year 2019. The map content is then distributed into annual program and put in a activities planning document as well as the annual budget with regard to improving the competence of lecturers in terms of knowledge, skills and profession as a vocational lecturers, as well as an evaluation and review of the achievement of compliance programs of quality of teachers (lecturers) in international standard. In order that the faculty capacity improvement program can be financed by the state budget, the concepts of developing the ability lecturers profession need to be approved and realized.

\section{c. The strategic alliance to respond to global competition}

Strategic alliance is an agreement between two or more partners to share knowledge or resources are based on the readiness, willingness, and ability and commitment to be involved in the process, so it will bring benefits to those who do $[15,16,17,18,19,20]$. The facts show that motivation, pre-conditions and strategic alliances that is done by STPs is basically oriented towards the achievement of the quality of graduates and to improve the quality of learning in the STP itself, and can provide benefits for the academic community, and in regard to institutions invited to do cooperation should have legality of the government and public recognition. Therefore, prior to the cooperation, STP must first conduct internal environmental analysis and the external environment analysis that is done to prepare STP conditions prior to cooperate with other parties. Motivation and precondition in partnering/alliance with other parties is basically oriented towards improving the quality of education to world class tourism higher education in accordance with the vision and mission of the institution so as to provide benefits to the academic community. Therefore, the institution must have criteria cluster who will be partners of STPs, developing partnerships with developed countries, to formulate a strategy and regulation in determining the cooperation partners.

Activities and substances of the alliances that is done by STPs incorporated into the strategic plan and annual plan in the form of key performance indicators quantitatively in each year. As for the subject matter or substances which is being aliened, among others includes the provision of education (joint program), the organization of Supervised Field Training (SFT) for STPs learners, graduate recruitment, and supports for the development of tourism education institutions. 
Points of cooperation as reference in support of the vision and mission of STPs includes the orientation of education in STPs, which is oriented to three advantages (exellency) of STP graduate outcomes: personal exellencies; social excellences; and environmental exellencies.

Where process of the decision-making regarding cooperation activities is collective. To observe the level of success of co-operations carried out with external parties is through partnership documentation evaluation.

Partnership activities and the substance being aliened STPs refers to the vision and mission of the institution, namely in order to produce graduates who have the advantage of competing on an international level, including the provision of education (joint program), the organization of SFT for learners STPs, graduate recruitment, and supports for the development of tourism education institutions.

Basically, the activities of alliances with other parties, is expected to provide many benefits to the entire academic community (students, graduates, faculty, staff), partners of educational institutions and the tourism industry.

Impact of the alliance is that STP Bandung and Bali have a strong confident to face the future in a global era. From the cooperation it is expected that student experience a "learning process" so that they have high confident, gain a good professional development in the context of skill, knowledge, and attitude.

\section{CONCLUSION AND SUGGESTION}

a. Strategic problems in Tourism Education in Indonesia

Strategic issues of graduates of competence of STPs, includes a decrease in the interest of prospective students to enroll; facilities, facilities for theory class, practice, and support facility is inadequate in quantity and quality; the TLA tend to be conventional and oriented to the hard skills; Tridharma of Higher Education has not run optimally; quality culture has not been institutionalized in the process of education.

Strategic issues of determinants of the quality of graduates of STPs, among others TLA tend to be introverted and conventional; low quality and the ability of faculty members in implementing the latest teaching methods and the standards of a higher education institution that global quality tourism does not meet yet; availability of infrastructure and educational facilities of both for the theory and practice are no longer sufficient to carry out world-class tourism education; qualification of human resources both educators and education personnel are not optimal; and limited budget for maintenaning of basic facilities and educational facilities.

Strategic issues of fulfillment of the standards of graduates quality and recognized by the international community at STPs, among others concerning the relevance of TLA with industry demands; the preparation of learners regarding the relative readiness enter the global competition is not optimal; programs and activities to sharp students soft skills and problem solving in the TLA is not optimal; and financing education is not based on the stages of vocational education. Strategic issues related to the quality of lecturers of global competitiveness at STP Bandung and Bali are relatively the similar i.e. either academic qualification of teachers regarding the professionalism and competence of Tridharma are not optimal.

b. Strategic Policy to Respond to the Needs of Human Resources Development for the Future Strategic policy of agency internal reform

conducted by STP Bandung and Bali, including through strategic planning in an effort to improve the quality of TLA; arrange Development Master Plan comprehensively using all aspects underlying the development and governance of higher education institutions; and improve the quality of TLA by implementing vocational school system consistently.

Strategic policy for revamping externally conducted STP Bandung and Bali, is through alliance with other higher education institutions and industry both at home and abroad concerning the implementation of orientation programs to industry, seminars/ workshops at home and abroad, joint-programs and dual degree in the field study of diploma, graduate and master level programs; training for faculty on research methodology and counseling.

Strategic policy of curriculum reform conducted STP Bandung and Bali, including through the implementation of the curriculum refers to the White Paper on which the implementation of the curriculum reform; implement and evaluate compliance with the Higher Education curriculum of DIKTI and Commont Asean Tourism Curriculum (CATC) by involving practitioners of the tourism industry plus experts in the field of education; to ask to external parties who have the competence to lecture certain subjects; and conduct professional development for all lecturers of courses according to the demands of the curriculum. 
Strategic policy of revamping lecturers done STPs, is through the creation of functional position of educator projection map until 2019 as a guide in the development of educators to achieve the standard of $40 \%$ of lecturers who have background in tourism education of higher education abroad and $70 \%$ educators who have CHE certification from AHLEI is distributed into planning documents as well as the activities of the annual budget; and conduct an annual review and evaluation of achievement of the program objectives of fulfillment of international quality educators; and through the organization of lecturers skills development program in accordance with the growing trend in the industry both at home and abroad.

\section{c. Strategic Alliance To Respond to Global Competition Motivation of STPs to form alliances with other}

parties is because of the encouragement to make STPs as an institution of leading tourism higher education ( $a$ notable tourism education institution); provide a guarantee for graduates to be able to work all over the world at different levels of the hierarchy; and in anticipation of the commencement of the ASEAN Free Trade Area, or ASEAN Economic Community in early 2015; and as a form of community service; viewed in terms of its ability and actual liability; advantage (benefit) will be found; to develop institutions; and because of limited resources, including human resources. Meanwhile, the pre-conditions that are taken into consideration by STP Bandung and Bali in alliance with other parties, including the readiness of organizations, educators, curriculum, and educational infrastructure; externally it is a factor in the reputation of the partners. The referral partnership orientation is the developed countries that are internationally recognized, at least with UNWTO-TedQual certification; and operating within the Republic of Indonesia.

Strategic alliances that is done by STPs a three stages strategy: the demand for the alliance, the initial discussions that are quite broad in scope, and produce the MoU as a bonds in favor of the points of cooperation in the form of formal ties and informal entered into strategic plans and annual plans as key performance indicators of the annual institution. To maintain the continuity of the alliance is done by developing communication through a monitoring program, and the annual event which is called Partnership Gathering. Meanwhile regarding the strategic alliance and the substance of activities undertaken by STPs is through several activities, including the provision of education with international partners; SFT implementation for learners of STPs; recruitment of graduates to work in various international tourism business; supporting the development of tourism education institutions in various parts of the country; providing education through distance learning mechanism.

The impact of the alliance for the academic community of STPs, including providing benefits to all parties, namely the students, graduates, partners, partners of educational institutions and the tourism industry; the academic community has a strong confident to face the future in the global era. The success of the partnership depends on a sense of mutual desire, and mutual interests.

\section{REFERENCES}

[1] Koster. (2005). Konsolidasi Pendidikan Kepariwisataan Indonesia. Bali: STP Bali.

[2] Baum. (2006). The Future of Work and Employment and Tourism. (D. Buhalis, \& C. Costa, Eds.) Tourism Management Dynamics , 130-136.

[3] Ghony, M., \& Almanshur, F. (2012). Metodologi Penelitian Kualitatif. Jogyakarta, West Java, Indonesia: Ar-Ruzz Media.

[4] Sadkar, U. (2010). Studi Manajement Mutu Pendidikan Kepariwisataan Berbasis TedQual System Pada STP Bandung. Bandung: SPs Indonesia University of Education.

[5] Kusmayadi, Sutomo, \& Suhendroyono. (2008). Pengembangan Bidang Ilmu Pariwisata. Kementerian Pendidikan . Jakarta: Direktorat Akademik Ditjen Dikti.

[6] Moleong, L. J. (2010). Metodologi Penelitian Kualitatif. Bandung, Jawa Barat, Indonesia: Remaja Rosdakarya.

[7] Bogdan, R. C., \& Biklen, S. K. (2007). Qualitative Research for Education: An Introduction to Theories and Methods. New York, USA: Pearson Education Group.

[8] Tribe, J., \& Airey, D. (2005). Issues for The Future. An International Handbook of Tourism Education , 501506.

[9] Gee, C. Y. (2002). Tourism Employment Issues. Human Resources in Tourism, 71-77.

[10] Fayos, S. E., Munez, A., \& Fuentes, L. (2011). Tourism as an Instrument for Development. Algavre: Universidad del Algevre, UNWTO. 
[11] Pangestu, M. E. (2014). Kesiapan Indonesia Menghadapi Asean Economy Community 2015 di Bidang Pariwisata dan Ekonomi Kreatif. Bandung: HILDIKTIPARI.

[12] Moira, e. (2008). Tourism Education and Training in Greece. ISTTE Conference (pp. 230-244). Dublin: International Society of Travel and Tourism Education.

[13] Baum, T. (2008). The Social Construction Skills : a hospitality sector perspective. European Journal of Vocational Training .

[14] Honey, M., \& Gilpin, R. (2009). Tourism in the Developing World: Promoting Peace and Reducing Poverty. Washington, USA: United States Institute for Peace.

[15] Dos, Y. L., Olk, P., \& Ring, P. (2000). Formation Process of R \& D Consortia. Strategic Management Journal $21,239-266$.

[16] Piana, D. L. (2008). Nonprofit Strategyy Revolution: Real-Time Strategic Planing in Rapid Respondse World. Fieldstone Alliance.

[17] Dent, S. M. (2006). Building Smart Alliance: Essential Component of a Successful Partnering Process. Partnering Intelligent.

[18] Gomes, \& Casseres, B. (2004). Managing Beyond the Alliance. Alliance Strategy, Centerpoint Institute.

[19] Gomes, e. a. (2003). Mastering Alliance Strategy: A Comprehensive Guide to Design, Management, and Organization . USA: John Wiley \& Sons.

[20] Gomes, C. B. (2006). How Alliances Reshape Competition. Handbook of Strategic Alliances Thousand Oaks, 39-54.

[21] Creswell, J. W. (2009). Research Design: Qualitative, Quantitative, and Mixed Methods Approaches (3rd Edition ed.). Los Angeles, California, USA: Sage Publications.

[22] Satori, D., \& Komariah, A. (2009). Metodologi Penelitian Kualitatif. Bandung: Alfabeta. 